\title{
NONOPERATIVE VERSUS OPERATIVE TREATMENT OF PATIENTS WITH DEGENERATIVE SPONDYLOLISTHESIS
}

\author{
TRATAMENTO CONSERVADOR VERSUS CIRÚRGICO DE PACIENTES \\ COM ESPONDILOLISTESE DEGENERATIVA \\ TRATAMIENTO CONSERVADOR CONTRA QUIRÚRGICO DE PACIENTES \\ CON ESPONDILOLISTESIS DEGENERATIVA
}

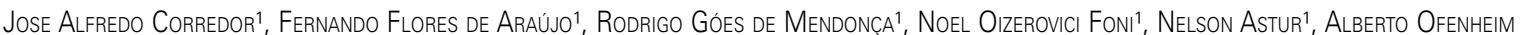

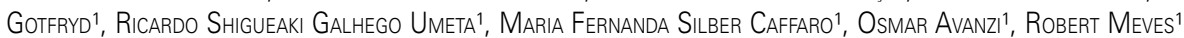

1. Irmandade da Santa Casa de Misericórdia de São Paulo, Medical School and Hospitals, Department of Orthopaedics andTraumatology, São Paulo, SP, Brazil

\begin{abstract}
Objective: To evaluate clinical and functional results of patients with lumbar degenerative spondylolisthesis treated with operatively or nonoperatively. Methods: Patients with degenerative spondylolisthesis treated either nonoperatively or operatively from 2004 to 2014 were selected from databases and a cross-sectional evaluation was performed. Outcome measures included back and leg visual analogue scales (VAS), Fischgrund criteria, Short Form-36 (SF-36) function score, and the modified Oswestry Disability Index (ODI). Results: 43 patients were evaluated: 20 with nonoperative treatment and 23 with operative treatment. Baseline characteristics were similar without significant differences between groups. Mean follow-up time was 43 months (range 10 - 72) for the nonoperative group and 36 months (range 6-80) for the operative group. Significant statistical difference in favor of operative group were found in back VAS (mean 4 versus $8, p=0.000$ ), leg VAS (mean 3 versus $6, p=0.0015$ ), SF-36 function score (mean 77 versus $35, p=0.000$ ), and ODI (mean 17 versus $46, p=0.000$ ). On the basis of the Fischgrund criteria, only $10 \%$ of patients reported excellent or good health post nonoperative treatment versus $83 \%$ for those treated operatively $(p=0.000)$. Conclusion: In this cross-sectional study, we observed that symptomatic patients with degenerative spondylolisthesis who underwent operative treatment have superior clinical and functional scores compared to those that underwent nonoperative treatment.
\end{abstract}

Keywords: Visual analog scale; Degenerative spondylolisthesis; Spine fusion; Spinal canal stenosis; SF-36; Surgery; Nonoperative treatment; lumbar spine; Intervertebral disc degeneration.

\section{RESUMO}

Objetivo: Avaliar os resultados clínicos e funcionais dos pacientes com espondilolistese degenerativa lombar tratados de maneira conservadora ou cirúrgica. Métodos: Foram selecionados pacientes com espondilolistese degenerativa tratados consenvadoramente ou submetidos à cirurgia, durante 2004-2014, à partir da coleta de dados que possibilitou a realização da avaliação transversal. As medidas de avaliação da dor lombar e das pernas foram escalas analógicas visuais (VAS), critérios Fischgrund, Short Form-36 (SF-36) pontuação funcional, e o Indice de Incapacidade Oswestry modificado (ODI). Resultados: 43 pacientes foram avaliados: 20 do tratamento conservador e 23 do tratamento cirúrgico. As características de base foram similares, sem diferenças significativas entre os grupos. O tempo médio de acompanhamento foi de 43 meses (intervalo 10-72) para o grupo não-cirúrgico e 36 meses (intervalo 6-80) para o grupo cirúrgico. Diferenças estatísticas significativas em favor do grupo cirúrgico foram encontrados no VAS lombar (média de 4 versus $8, p=0,000$ ), VAS pernas (média 3 contra 6, $p=0,0015$ ), SF-36 pontuação funcional (média 77 versus 35, $p=0,000$ ), e ODI (média 17 versus 46, $p=0,000$ ). Com base nos critérios Fischgrund, apenas 10\% dos pacientes relataram excelente ou boa saúde de após o tratamento consenador contra 83\% para aqueles tratados no cirúrgico ( $p=0,000$ ). Conclusão: Neste estudo transversal, observou-se que os pacientes sintomáticos com espondilolistese degenerativa que se submeteram ao tratamento cirúrgico têm escores clínicos e funcionais superiores em comparação àqueles que foram submetidos a tratamento consenvador.

Descritores: Escala visual analógica; Espondilolistese degenerativa; Fusão vertebral; Estenose do canal vertebral; SF-36; Cirurgia; Tratamento conservador; Coluna lombar; Degeneração do disco intervertebral.

\section{RESUMEN}

Objetivo: Evaluar los resultados clínicos y funcionales de los pacientes con espondilolistesis degenerativa lumbar tratados quirúrgicamente o sin cirugía. Métodos: Se realizó una evaluación transversal de los pacientes con espondilolistesis degenerativa, registrados en la base de datos, tratados conservador o quirúrgicamente desde 2004 hasta 2014. Las medidas de desenlace incluyeron: Escala Visual Análoga (EVA) de dolor lumbar y las piernas, criterios de Fischgrund, Short Form-36 (SF-36) e Índice de Discapacidad Oswestry modificado (IDO). Resultados: Se evaluaron 43 pacientes: 20 con tratamiento no quirúrgico y 23 con tratamiento quirúrgico. Las características de base fueron similares, sin diferencias significativas entre los grupos. El tiempo medio de seguimiento fue de 43 meses (rango 10-72) para el grupo no quirúrgico y 36 meses (rango 6-80) para el grupo quirúrgico. Diferencias estadísticamente significativas a favor del grupo quirurgico fueron encontrados en EVA lumbar (media 4 contra 8, $p=0,000$ ), EVA pierna (media 3 contra 6, $p=0,0015$ ), SF-36 función (media 77 contra 35, $p=0,000$ ), e IDO (media 17 contra $46, p=0,000)$. Con respecto a los criterios de Fischgrund, sólo el 10\% de los pacientes del grupo que recibió tratamiento no quirúrgico informo excelente o buen estado de salud en comparación con 83\% de los que recibieron manejo quirúrgico $(p=0,000)$ Conclusión: En este estudio de corte transversal, se observó que los pacientes sintomáticos con espondilolistesis degenerativa que se sometieron a tratamiento quirúrgico tienen puntuaciones clínicas y funcionales superiores en comparación con los que se sometieron a tratamiento no quirúrgico.

Descriptores: Escala visual análoga; Espondilolistesis degenerativa; Fusión vertebral; Estenosis del canal vertebral; SF-36; Cirugía; Tratamiento conservador; Columna lumbar; Degeneración del disco intervertebral. 


\section{INTRODUCTION}

Degenerative spondylolisthesis is regarded as one of the leading causes of back pain in patients over 50 . The condition is characterized by the slippage of one vertebra forward onto the vertebra below, with no identifiable defect in the posterior neural arch. The pathological process comprises disc and facet degenerative changes. ${ }^{1,2}$ It is more common in Afro-descendants than in Caucasians, and more prevalent in women than in men. ${ }^{1-3}$

In symptomatic patients with absence of neurologic deficits the consensus is for conservative management. Around $83 \%$ of patients with long-standing refractory back pain, sensory changes, muscle weakness, history of neurogenic claudication, or cauda equina syndrome deteriorate and should be submitted to surgical treatment. ${ }^{2}$ Neurogenic claudication is due to the onset of concomitant lumbar stenosis secondary to the slippage, hypertrophy of the yellow ligament and occupation of the vertebral canal by osteophytes resulting from facet arthrosis. ${ }^{1}$

Grade I evidence about the best treatment of patients with degenerative spondylolisthesis are not available in the literature. The Spine Patient Outcomes Research Trial (SPORT) ${ }^{4}$ published a research on the subject comparing nonoperative and surgical treatment. This four-year multi-center trial shows that the group submitted to surgery attained comparatively marked improvement in pain and function after failure of conservative treatment for 6 months. ${ }^{4}$

The aim of the present cross-sectional study was to assess the clinical and functional outcomes of patients with degenerative spondylolisthesis submitted to nonoperative or surgical treatment.

\section{METHODS}

A cross-sectional study involving retrospective selection of patients diagnosed with degenerative spondylolisthesis submitted to nonoperative or surgical treatment in the last 10 years by the Spine Surgery Group of our institution was conducted. Selected participants were invited to undergo clinical and functional follow-up assessment. The inclusion criterion was subjects diagnosed with degenerative spondylolisthesis confirmed by medical records and radiographs, presence of neurogenic claudication or radicular leg pain, candidate to surgical decompression and fusion, and with at least six months of follow-up. Patients refusing to take part in the study, those with a diagnosis other than degenerative spondylolisthesis (dysplastic, isthmic, traumatic and/or pathologic), patients without confirmed diagnosis (incomplete medical records or missing imaging exams) and patients not located for follow-up assessment were excluded. The study was submitted to and approved by the Institutional Review Board of our hospital prior to data collection. All patients signed a free and informed consent form (C.A.A.E 23056513.8.0000.5479).

Patients indicated for surgical treatment on the waiting list who were receiving conservative treatment constitute the nonoperative group. The protocol applied for these patients consisted of general guidance for pain control such as: physiotherapy sessions and postural education with changes in usual life-style habits and home-based exercises, non-steroidal anti-inflammatory drugs when tolerated, in addition to systematic reassessments in outpatient follow-up for six months. The surgical group was constituted by patient submitted to posterior decompression and pedicle-screw instrumentation with autologous grafting at the levels affected.

Clinical outcomes were assessed using the Visual Analog Scale (VAS) for back and leg pain and the Fischgrund criteria, ${ }^{5}$ (excellent: asymptomatic patient without limitations in daily activities; good: sporadic pain - back pain or radiculopathy- with occasional use of analgesics, yet without restriction in daily activities; regular: intermittent pain or radiculopathy, with regular use of analgesic medication, restriction in daily activities, yet improved compared to preoperative condition, poor: frequent pain and/or radiculopathy with continuous use of analgesics and major restrictions in daily activities, with no postoperative improvement. Functional and quality-of-life outcomes were assessed by the Oswestry Disability Index (ODI) score, ${ }^{6}$ and Short-Form 36 (SF - 36) function score, ${ }^{7}$ respectively.
All patients obtained anteroposterior, lateral and flexion-extension lumbar radiographs at baseline and recent follow-up. Radiological evaluation included baseline and current slippage grade according to Meyerding classification. ${ }^{8}$ Bone fusion was evaluated in patients submitted to surgical treatment, according to Linovitz criteria. ${ }^{9}$ This is measured on a 4 grade scale - grade zero: discontinuity of the fusion mass with motion; grade one: a narrow band of continuity in the fusion mass with motion; grade two: continuity of the fusion mass without motion; and grade three: extensive continuity of the fusion mass without motion - considering grades zero and one failed fusion, and grades two and three successful fusion.

\section{Statistical Analysis}

Clinical and functional outcomes were analyzed between both groups for data collected during the follow-up assessment. Radiographic outcomes were analyzed for baseline and recent evaluation. Associations between the different demographic characteristics were measured using Fisher's exact test. For continuous variables, $t$ test was used to test means and generate $p$ values. For categorical variables, Fisher's exact test was used to test generate $p$ values. Analysis was carried out using statistical software STATA, version 12.0. A p-value of $<0.05$ was deemed statistically significant.

\section{RESULTS}

A total of 43 patients were assessed; 20 submitted to nonoperative treatment and 23 to surgical treatment. Table 1 shows a homogenous demographic distribution, with no statistically significant difference between groups. Mean follow-up was 43 months (range 10 - 72) in nonoperative group and 36 months (range 6-80) in the surgical group. Groups were also stratified according to spondylolisthesis grade and level involved (Table 1). Based on Fischgrund criteria, no patients $(0 \%)$ had excellent outcomes, two patients had (10\%) good outcomes, 10 patients (50\%) had regular outcome and eight patients (40\%) had a poor outcome in the nonoperative group. In the surgical group, nine patients (39\%) had excellent outcomes, 10 patients (44\%) good outcome, four patients (17\%) regular outcome and no patients $(0 \%)$ had a poor outcome $(p=0.000)$

Figure 1 shows the comparative results of the VAS for back and leg pain for both groups. Results on SF-36 function score showed a mean of 35 (Standard Deviation: 24) for the nonoperative group and 77 (Standard Deviation: 16) for the surgical group. On the ODI scale, the mean was 46 (Standard Deviation: 21) for the nonoperative group and 17 (Standard Deviation: 14) for the surgical group. Significant statistical difference in favor of surgical group was found in both scales $(p=0.000)$.

No complications occurred in the nonoperative group, whereas two cases of infection were detected in the surgical group, both successfully treated with antibiotics.

According to Linovitz criteria grade three was seen in 12 patients (52\%), grade two in seven patients (31\%) and grade one in four patients (17\%). No patients in grade zero were found.

Progression of the slippage from grade 1 to grade 2 occurred in two patients (10\%) in the nonoperative group and in two patients $(9 \%)$ in the surgical group. These patients were correlated with the

Table 1. Demographic distribution of nonoperative and surgical groups.

\begin{tabular}{c|c|c|c}
\hline \multirow{2}{*}{} & \multicolumn{2}{|c|}{ Demographic variables } & \\
\cline { 2 - 4 } & $\begin{array}{c}\text { Nonoperative } \\
\mathbf{n ~ ( 2 0 )}\end{array}$ & $\begin{array}{c}\text { Surgical } \\
\mathbf{n ~ ( 2 3 )}\end{array}$ & \\
\hline Age & 61 years (43-81) & 56 years (43-80) & $\mathrm{p}=0.13$ \\
\hline \multirow{2}{*}{ Gender } & M: $5(25 \%)$ & M: $5(22 \%)$ & $\mathrm{p}=0.8$ \\
\hline Follow-up & F: $15(75 \%)$ & F: $18(78 \%)$ & $\mathrm{p}=0.29$ \\
\hline Spondylolis- & I: $12(60 \%)$ & I: $11(48 \%)$ & \\
thesis Grade & II: $8(40 \%)$ & II: $12(52 \%)$ & \\
\hline \multirow{2}{*}{ Level } & L4-L5: $8(40 \%)$ & L3-L4: $1(5 \%)$ & \\
& L5-L5: $10(43 \%)$ & \\
& & L5-S1: $10(43 \%)$ & \\
\hline
\end{tabular}




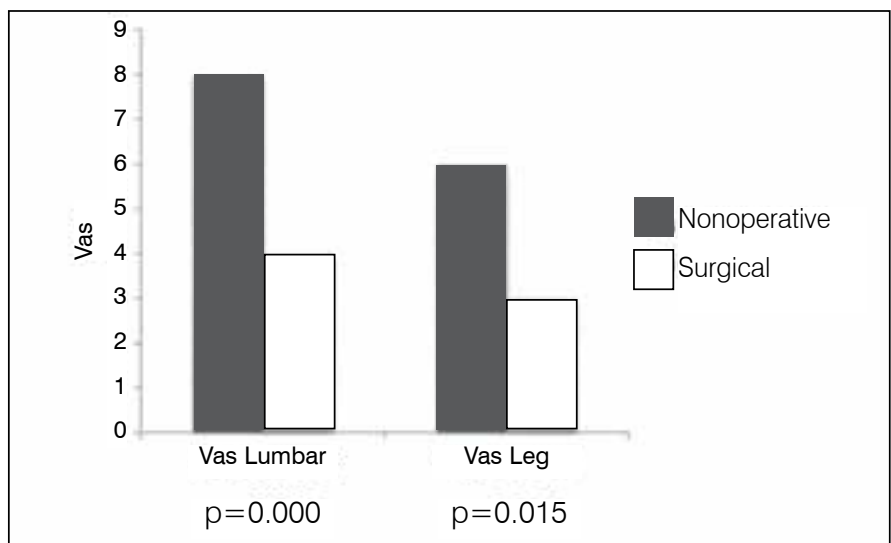

Figure 1. Comparative results of Visual Analogue Scale for back pain and leg pain between nonoperative and surgical treatment.

outcomes. This analysis revealed that patients in the surgical group with slippage had the worst scores.

\section{DISCUSSION}

Results of the present cross-sectional study showed that better scores for back VAS, leg VAS, SF-36 function score and ODI scales were attained by the surgical treatment group with significant statistical difference. In the surgical group, $83 \%$ of patients rated their general health post treatment as excellent or good compared with $10 \%$ of patients in the nonoperative group. However, the surgical procedure was associated with a higher number of complications.

Previous studies have shown better clinical and functional outcomes in patients undergoing surgical treatment. On a multicenter study, Weinstein et al., ${ }^{4}$ compared patients with degenerative spondylolisthesis associated with vertebral canal stenosis treated nonoperatively or surgically. On the intent-to-treat analysis, the surgical group achieved greater pain relief and function improvement measured by the ODI and SF-36 at 4 years follow-up. To our knowledge this is the only study published reporting this type of comparison. A large number of articles are available in the literature comparing nonoperative and surgical management of patients with lumbar stenosis, but these studies include patients with a broad diagnosis of degenerative lumbar spondylosis: lumbar disc herniation, spondylolisthesis and vertebral stenosis. ${ }^{10}$
Due to the scarcity of spinal surgery centers in our country, there are long waiting lists for elective surgery within the public health care setting. This created a cohort of patients followed over time that despite being surgical candidates, received nonoperative treatment while awaiting surgery. Furthermore, this flaw in the health care system creates an unconventional opportunity to observe and evaluate natural history of degenerative spondylolisthesis when surgery is indicated but not performed. We were able to compare this group of "undertreated" patients with similar baseline characteristics than those who received surgical decompression and stabilization of the lumbar listhesis.

The most commonly affected level for degenerative spondylolisthesis is at L4-5. This level exhibits more sagittal facing facets which, in combination with the more coronal orientation of the L5/ $\mathrm{S} 1$ facets, reduce the capacity to resist flexion forces. This thereby increases the tendency for vertebral slippage and facet degeneration. ${ }^{1,2,5,11}$ In the present study, L5-S1 level was found to be the most affected in the two groups. One explanation for this phenomenon may be because the center involved is a reference center for spinal pathology and therefore the most severe cases are referred. The fusion rate found in the surgical patients (83\%) was in agreement with rates reported in the literature. ${ }^{4,12}$ Likewise, the demographic results of the sample were similar to data found in the literature, $1,4,11$

The main limitation of the present study was the lack of baseline data, which hampered quantitative analysis between groups along the treatment. Further limitations were a small sample size and non-randomized patient selection. For these reasons, results should be interpreted cautiously.

\section{CONCLUSION}

In this cross-sectional study, we observed that symptomatic patients with degenerative spondylolisthesis who underwent surgical treatment have superior clinical and functional scores compared to those that underwent conservative treatment.

\section{ACKNOWLEDGMENTS}

We thank the Support Center for Publication of the Faculty of Medical Sciences of Santa Casa de São Paulo - NAP-SC for technical support of the publication of this manuscript

The lead author get a AOSpine internship during the study. During this period, he received a AOSpine Latin America scholarship.

CONTRIBUTIONS OF THE AUTHORS: Each author made a significant individual contribution to the development of the manuscript. JAC was responsible for the design and outline, acquisition and interpreting of the data, statistical analysis, writing the manuscript, and the final approval. FFA made an effective scientific and intellectual contribution to the study, design and outline, the data acquisition, and the writing of the manuscript. RGM made an effective scientific and intellectual contribution to the study, the data acquisition, and the writing of the manuscript. NOF contributed to the study outline and data acquisition. NA contributed to the writing of the manuscript, critical revision, and final approval. AOG, RSGU, MFSC and OA made effective scientific and intellectual contributions to the study and the critical revision. RM made an effective scientific and intellectual contribution to the study, design and outline, the critical review, and the final approval.

\section{REFERENCES}

1. Majid K, Fischgrund JS. Degenerative lumbar spondylolisthesis: trends in management. J Am Acad Orthop Surg. 2008:16(4):208-15.

2. Watters WC 3rd, Bono CM, Gilbert TJ, Kreiner DS, Mazanec DJ, Shaffer WO, et al. An evidence-based clinical guideline for the diagnosis and treatment of degenerative lumbar spondylolisthesis. Spine J. 2009;9(7):609-14.

3. Rodrigues LMR, Ueno FH, Santiago Filho EV, Nicolau RJ, CarvalhoTD, Yonezaki AM, et al. Espondilolistese degenerativa: avaliação da qualidade de vida dos pacientes submetidos a tratamento cirúrgico. Arq Bras Ciênc Saúde; 2010;35(1):12-4

4. Weinstein JN, Lurie JD, Tosteson TD, Zhao W, Blood EA, Tosteson AN, et al. Surgical compared with nonoperative treatment for lumbar degenerative spondylolisthesis. four-year results in the Spine Patient Outcomes Research Trial (SPORT) randomized and observational cohorts. J Bone Joint Surg Am. 2009:91(6):1295-304.

5. Fischgrund JS, Mackay M, Herkowitz HN, Brower R, Montgomery DM, Kurz LT. 1997 Volvo Award winner in clinical studies. Degenerative lumbar spondylolisthesis with spinal stenosis: a prospective, randomized study comparing decompressive laminectomy and arthrodesis with and without spinal instrumentation. Spine (Phila Pa 1976). 1997;22(24):2807-12

6. Daltroy LH, Cats-Baril WL, Katz JN, Fossel AH, Liang MH. The North American spine society lumbar spine outcome assessment Instrument: reliability and validity tests. Spine (Phila Pa 1976). 1996:21(6):741-9.

7. McHorney CA, Ware JE Jr, Lu JF, Sherbourne CD. The MOS 36-item Short-Form Health Survey (SF-36): III. Tests of data quality, scaling assumptions, and reliability across diverse patient groups. Med Care. 1994:32(1):40-66.

8. Meyerding HW. Spondyloptosis. Surg Gynaecol Obstet. 1932;54:371-7.

9. Linovitz RJ, Pathria M, Bernhardt M, Green D, Law MD, McGuire RA, et al. Combined magnetic fields accelerate and increase spine fusion: a double-blind, randomized, placebo controlled study. Spine (Phila Pa 1976). 2002:27(13):1383-9.

10. Jacobs WC, Rubinstein SM, Koes B, van Tulder MW, Peul WC. (2013) Evidence for surgery in degenerative lumbar spine disorders. Best Pract Res Clin Rheumatol. 2013 Oct:27(5):673-84.

11. Steiger F, Becker HJ, Standaert CJ, Balague F, Vader JP, Porchet F, et al. Surgery in lumbar degenerative spondylolisthesis: indications, outcomes and complications. A systematic review. Eur Spine J. 2014;23(5):945-73.

12. Kornblum MB, Fischgrund JS, Herkowitz HN, Abraham DA, Berkower DL, Ditkoff JS Degenerative lumbar spondylolisthesis with spinal stenosis: a prospective long-term study comparing fusion and pseudarthrosis. Spine (Phila Pa 1976). 2004;29(7):726-33. 